DOI: https://doi.org/10.24127/ajpm.v10i4.4211

\title{
PENERAPAN MEDIA PROLIBRA UNTUK MENINGKATKAN KEMAMPUAN PENALARAN MATEMATIS DAN SELF CONFIDENCE SISWA
}

\author{
Riezky Purnama Sari ${ }^{1}$, Fairus $^{2 *}$, Hanafiah ${ }^{3}$ \\ ${ }^{1,2 *}, 3$ Universitas Samudra, Langsa, Indonesia \\ *Corresponding author \\ E-mail: $\quad$ riezkypurnamasari@gmail.com ${ }^{1)}$ \\ fairuz@unsam.ac.id ${ }^{2^{*}}$ \\ $\underline{\text { hanafiah1969.mpd@gmail.com }}^{3)}$
}

Received 10 September 2021; Received in revised form 17 November 2021; Accepted 28 December 2021

\begin{abstract}
Abstrak
Tujuan penelitian ini adalah untuk mengetahui peningkatan kemampuan penalaran matematis dan self confidence siswa SMKN 1 Langsa dengan menggunakan media PROLIBRA. Jenis penelitian yang digunakan dalam penelitian ini adalah penelitian Quasi eksperimen dengan desain Randomized control group pretest-posttest. Teknik pengumpulan data yang digunakan dalam penelitian ini adalah tes dan angket. Penelitian ini mengambil populasi kelas XI SMKN 1 Langsa dengan sampel kelas XI MM1 sebagai kelas eksperimen, dan XI MM2 sebagai kelas kontrol. Hasil analisa data diperoleh peningkatan kemampuan penalaran matematis siswa melalui media pembelajaran PROLIBRA lebih baik dari pada melalui pembelajaran tanpa media POLIBRA pada materi program linear di kelas XI SMKN 1 Langsa. Pada kelas eksperimen yang diajarkan dengan media polibra ada peningkatan self-confidence pada aspek keyakinan terhadap kemampuan diri sendiri untuk memahami matematika 80,25\% dengan kategori baik; aspek keyakinan diri untuk dapat terus belajar matematika 79,58\% dengan kategori baik; dan aspek keyakinan diri dapat mengatasi rintangan dalam menyelesaikan masalah 79,37\% dengan kategori Baik. Sedangkan pada kelas kontrol peningkatan self-confidence terjadi pada aspek keyakinan terhadap kemampuan diri sendiri untuk memahami matematika 76,75\% dengan kategori baik, aspek yg lainnya juga terlihat sedikit meningkat walaupun masih berada pada kategori cukup.
\end{abstract}

Kata kunci: Kemampuan penalaran matematis; media Prolibra; self confidence.

\begin{abstract}
The purpose of this study was to determine the increase in mathematical reasoning ability and selfconfidence of SMKN 1Langsa students using PROLIBRA media. The type of research used in this study is a quasi-experimental study with a randomized control group pretest-posttest design. Data collection techniques used in this study were tests and quiestionnaires. This study took the population of class XI SMKN 1 Langsa with samples of class XI MMI as the experimental class, and XI MMI as the control class. The results of data analysis showed that the increase in students' mathematical reasoning abilities through PROLIBRA learning media was better than through learning without PROLIBRA media on linear programming material in class XI SMKN 1 Langsa. In the experimental class taught with prolibra media, there was an increase in self-confidence in the aspect of confidence in one's ability to understand mathematical $80,25 \%$ in the good category; aspects of self-confidence to be able to continue learning mathematics 79,58\% with good category; and aspects of self-confidence can overcome obstacles in solving problems $79,37 \%$ in the good category. While in the control class, the increase in self-confidence occurred in the aspects of confidence in one's own ability to understand mathematics 76,75\% in the good category, the other aspects also showed a slight increase even though they were still in the sufficient category.
\end{abstract}

Keywords: Mathematical reasoning ability; Prolibra media; self confidence.

This is an open access article under the Creative Commons Attribution 4.0 International License 
DOI: https://doi.org/10.24127/ajpm.v10i4.4211

\section{PENDAHULUAN}

Dunia pendidikan di abad 21 yang terus berkembang dengan signifikan menuntut seluruh unsur-unsur pendidikan seperti pendidik, peserta didik hingga proses pembelajaran untuk menyesuaikan diri dengan kebutuhan dan perkembangan zaman. Diakui dalam perkembangan kehidupan dan ilmu pengetahuan abad 21, kini memang telah terjadi pergeseran baik ciri maupun model pembelajaran (Sajidan, Baedhowi, Triyanto, Totalia, \& Masykuri , 2018).

Perkembangan tersebut juga terjadi di sekolah menengah kejuruan (SMK) di Kota Langsa, dimana Sekolah Menengah Kejuruan (SMK) merupakan lembaga pendidikan yang bertujuan mencetak lulusan yang memiliki keterampilan untuk memenuhi kebutuhan dunia kerja baik di tingkat nasional maupun internasional. Salah satu bekal lulusan SMK agar siap masuk dalam bursa kerja yaitu kemampuan bernalar, kepercayaan diri dan penguasaan dalam teknologi. Hal ini senada dengan pendapat Miller \& Northern yang menyatakan bahwa Pendidikan saat ini diharapkan dapat menghasilkan SDM yang memiliki kemampuan komunikasi dan kolaborasi yang kuat, ahli dalam menggunakan teknologi, keterampilan berpikir kreatif dan inovatif serta kemampuan untuk memecahkan masalah (Larson \& Miller, 2011).

Ball dan Bass (Arifendi \& Setiawan, 2019) mengungkapkan bahwa penalaran matematis adalah "dasar" keterampilan matematika. Sedangkan, Self confidence merupakan suatu sikap atau perasaan yakin atas kemampuan diri sendiri sehingga orang yang bersangkutan tidak terlalu cemas dalam tindakan-tindakannya, dapat merasa bebas untuk melakukan hal-hal yang disukainya, bertanggung jawab atas tindakannya, hangat dan sopan dalam berinteraksi dengan orang lain, memiliki dorongan untuk berprestasi serta mengenal kelebihan dan kekurangan dirinya (Andayani \& Amir, 2019).

Kemampuan bernalar sangatlah penting untuk dimiliki oleh siswa termasuk siswa SMK, karena penalaran merupakan suatu proses atau aktivitas berpikir yang menggunakan logika untuk menarik sebuah kesimpulan dari fakta yang ada, dengan proses bernalar siswa mampu mengembangkan keterampilan komunikasi, keterampilan berpikir kreatif dan inovatif untuk menghadapi berbagai masalah di dunia kerja nantinya, karena menurut Agustin (Agustin, 2016) kemampuan bernalar berperan penting baik dalam pemahaman konsep maupun pemecahan masalah

Kemampuan bernalar juga dibutuhkan siswa untuk memahami materi pelajaran termasuk pelajaran matematika, karena penalaran merupakan dasar keterampilan matematika. Mengutip O'Daffler dan Thornquist (Fairman, Peckham, Rucker, Rucker, \& Sclar, 2018), kedua penulis selanjutnya mengatakan penalaran matematik, yang memainkan peran mutlak dalam proses berpikir, meliputi mengumpulkan fakta, membuat dugaan, membuat perumuman, membangun argumen, dan menarik (dan menyahihkan) simpulan logis mengenai beragam gagasan itu dan hubungan-hubungannya.

Kemampuan penalaran matematis dapat di tingkatkan melalui pemanfaatan $T I K$, hal ini senada dengan hasil penelitian Zulkarnaen (Zulkarnaen, 2016) yang menyatakan bahwa kemampuan penalaran matematis siswa yang memperoleh berbantuan TIK lebih baik dibanding siswa yang tidak. Selain itu, pemanfaatan TIK dalam pembelajaran 
matematika bisa membuat siswa untuk tertarik dalam pembelajaran (Bernard, 2015), hal ini sesuai dengan hasil penelitian Fairus (Fairus, 2015) yang menyatakan bahwa Perangkat pembelajaran yang dikembangkan berbantuan Autograph dapat meningkatkan kemampuan penalaran matematis. Selain penalaran pemanfaatan TIK juga dapat meningkatkan kemampuan kepercayaan diri atau Self confidence siswa selama pembelajaran (Sholeha, Novianti, \& Chotimah, 2019).

Penguasaan teknologi informasi dan komunikasi (TIK) khususnya komputer di abad 21 ini merupakan sumber belajar, media belajar maupun menjadi media komunikasi. TIK tidak lagi menjadi mata pelajaran terpisah melainkan terintegrasi dalam setiap mata pelajaran. Dengan kata lain kompetensi pemanfaatan TIK menjadi salah satu kompetensi wajib yang harus dikuasai setiap pendidik. Salah satu pelajaran yang menerapkan pembelajaran abad 21 yang memanfaatkan teknologi atau TIK yaitu matematika, dan salah satu penggunaan TIK yang cocok pada pembelajaran matematika untuk sekolah menengah adalah dengan menggunakan software Geogebra (Fairus \& Sari, 2020). Hal ini juga sesuai dengan pendapat Budiman dan Rosmiati (2020) kemampuan penalaran matematis siswa yang mendapat pembelajaran dengan bantuan Geogebra lebih baik daripada kemampuan penalaran matematis siswa yang tidak mendapat bantuan Geogebra. Sejalan dengan itu, hasil penelitian Sunaryo (2019) menjelaskan bahwa Penggunaan Media Pembelajaran Geogebra dapat meningkatkan hasil belajar siswa.

Berdasarkan observasi awal yang dilakukan di sekolah SMKN 1 Langsa melalui wawancara terhadap beberapa guru matematika, kesulitan terjadi pada materi program linier, terutama dalam menentukan daerah pertidaksamaan $a x-b y>0, \quad a x-b y<0,-a x-$ by $>0,-a x-b y>0$, siswa juga kesulitan menyajikan pernyataan matematika secara lisan atau tulisan, dan tidak mampu membuat kesimpulan, memberikan alasan atau bukti terhadap beberapa solusi. Hal tersebut dikarenakan penalaran matematis yang rendah dan siswa mengalami krisis kepercayaan diri (Self confidence).

Berdasarkan uraian diatas, penelitian ini penting dilakukan untuk meningkatkan kemampuan penalaran matematis dan Self confidence siswa SMKN 1 Langsa dengan membuat suatu media PROLIBRA yaitu media pembelajaran program linier yang memanfaatkan aplikasi Geogebra.

\section{METODE PENELITIAN}

Jenis penelitian ini adalah penelitian Quasi eksperimen dengan desain penelitian randomized control group pretest-posttest (Sugiyono, 2016)

$$
\begin{array}{lllll}
\mathrm{A}_{1}: & \mathrm{T}_{0} & \mathrm{X} & \mathrm{T}_{1} \\
\mathrm{~A}_{2}: \mathrm{T}_{0} & - & \mathrm{T}_{1}
\end{array}
$$

Keterangan :

$\mathrm{T}_{0}:$ Pretest penalaran matematis

$\mathrm{T}_{1}$ : posttest penalaran matematis

$\mathrm{A}_{1}$ : Kelas Eksperimen

$\mathrm{A}_{2}$ : Kelas Kontrol

$\mathrm{X}$ : Perlakuan pada kelas eksperimen dengan menggunakan media pembelajaran POLIBRA

Adapun populasi dari penelitian ini adalah seluruh peserta didik kelas XI MM SMKN 1 Langsa. Sedangkan sampel penelitian diambil kelas XI MM1 (kelas eksperimen) dan XI MM2 (kelas control). Teknik pengumpulan data berupa tes penalaran matematis dan angket Self cofidence. 
DOI: https://doi.org/10.24127/ajpm.v10i4.4211

\section{Teknik Analisis Data}

a) Analisis statistik deskriptif

Analisis ini digunakan untuk melihat gambaran dari data berupa rataan, variansi, min, max, kurtosis dan skweness.

b) Analisis kemampuan penalaran matematis

Kemampuan penalaran matematis ditandai dengan lima indikator, yaitu; (1) Kemampuan menyajikan pernyataan matematika secara lisan, tertulis, gambar, dan diagram, (2) Kemampuan mengajukan dugaan, (3) Kemampuan melakukan manipulasi matematika, (4) Kemampuan menyusun bukti, memberikan alasan terhadap suatu solusi. (5) Kemampuan menarik kesimpulan dari pernyataan.

Untuk melihat peningkatan kemampuan penalaran siswa, maka menggunakan rumus g-faktor ( $N$-Gain) yang dikemukakan Meltzer (Pratiwi, 2016) sebagai berikut:

$$
\left.G=\frac{T_{1}-T_{0}}{T_{m a k s}-T_{0}} \quad \ldots \ldots \ldots 1\right)
$$

Dengan :

$\mathrm{G}=$ skor gain ternormalisasi

$\mathrm{T}_{0} \quad=$ skor pretest

$\mathrm{T}_{1} \quad=$ skor postest

$\mathrm{T}_{\text {maks }}=$ skor maksimum ideal

Adapun kategorisai dari skor gain ternormalisai yang diperoleh dapat dilihat pada Tabel 1.

Tabel 1. Kriteria tingkat gain

\begin{tabular}{cc}
\hline Gain $\mathbf{( g )}$ & Kriteria \\
\hline$g>0,7$ & Tinggi \\
$0,3<g \leq 0,7$ & Sedang \\
$g \leq 0,3$ & Rendah \\
\hline
\end{tabular}

c) Analisis statistik inferensial

Hipotesis dalam penelitian ini, yaitu :

1. $H_{0}: \mu_{1} \leq \mu_{2}:$ Peningkatan

penalaran matematis siswa melalui media pembelajaran POLIBRA tidak lebih baik dari pada melalui pembelajaran tanpa media POLIBRA pada materi program linear di kelas XI SMKN 1 Langsa

2. $H_{1}: \mu_{1}>\mu_{2}: \quad$ Peningkatan penalaran matematis siswa melalui media pembelajaran POLIBRA lebih baik dari pada melalui pembelajaran tanpa media POLIBRA pada materi program linear di kelas X SMKN 1 Langsa

Data yang diperoleh kemudian akan diolah dengan menggunakan software SPSS kemudian diinterpretasikan.

\section{d) Analisis kuantitatif Self Cofidence}

Tingkat kepercayaan diri (Self confidence) siswa dalam penelitian ini diukur melalui angket berdasarkan aspek-aspek Self confidence yaitu: (1) keyakinan terhadap kemampuan diri sendiri untuk memahami matematika, (2) keyakinan diri dapat menyelesaikan masalah-masalah matematik, keyakinan diri untuk dapat terus belajar matematika, dan (4) keyakinan diri dapat mengatasi rintangan dalam menyelesaikan masalah (Minarni, Napitupulu, \& Lubis, 2020). Analisa data angket Self cofidence menggunakan skala Likert (Budiaji, 2013) yang mempunyai empat pilihan jawaban, yakni sangant setuju (SS), Setuju, Tidak setuju (YS), sangat tidak setuju (STS). Adapun penskoran dari skala Likert dapat dilihat pada Tabel 2 . 
DOI: https://doi.org/10.24127/ajpm.v10i4.4211

Table 2. Skor Angket Self confidence

\begin{tabular}{cc}
\hline Jawaban & Skor \\
\hline Sangat Setuju (SS) & 4 \\
Setuju (S) & 3 \\
Tidak Setuju (TS) & 2 \\
Sangat Tidak Setuju & 1 \\
\hline
\end{tabular}

Perhitungan persentase hasil penskoran menggunakan rumus berikut:

$$
\mathrm{N}=\frac{\text { Skor perolehan }}{\text { Skor maksimal }} \text { X } 100 \% \ldots \text { 2) }
$$

Kemudian data kuantitatif yang sudah diperoleh diubah menjadi data kualitatif dengan kriteria dapat dilihat pada Tabel 3.

Tabel 3. Kriteria nilai persentase self cofindence

\begin{tabular}{cc}
\hline Rentang Nilai (\%) & Kategori Sikap \\
\hline $25-50$ & Kurang \\
$51-75$ & Cukup \\
$76-100$ & Baik \\
\hline
\end{tabular}

Sumber: (Arikunto, 2010)

\section{HASIL DAN PEMBAHASAN}

Kegiatan yang dilakukan saat penelitian ini adalah memberikan soal pretest dan angket Self cofidence yang berkenaan dengan materi program linear dan indikator penalaran matematis pada kelas eksperimen dan kelas kontrol. Pada tahap selanjutnya, melaksanakan proses pembelajaran dengan menggunakan media pembelajaran POLIBRA pada kelas eksperimen dan proses pembelajaran tanpa menggunakan media pembelajaran POLIBRA pada kelas kontrol sebanyak tiga kali pertemuan setiap kelasnya. Kemudian pada tahap terakhir, guru memberikan soal posttest dan angket Self cofidence pada kelas eksperimen dan kelas kontrol.
Data pretest, postest dan selfconfident pada tulisan ini diolah dengan bantuan sofware SPSS dan MS. Excel. Analisa data diawali dengan statistika deskriptif kemudian dilakukan pengujian hipotesis serta analisa angket self-cofindence.

a. Statistika deskriptif

Tujuan statistika deskriptif ialah untuk melihat gambaran awal data. Hasil statistika deskriptif dari perolehan hasil pretest dan postest pada kelas eksperimen dan kelas kontrol dapat dilihat pada Tabel 4.

Tabel 4. Statistika deskriptif nilai pretest dan posttest kelas eksperimen dan kontrol

\begin{tabular}{|c|c|c|c|}
\hline No $\begin{array}{c}\text { Jenis } \\
\text { tes }\end{array}$ & Kelas & $\begin{array}{c}\text { Komponen } \\
\text { Statistik } \\
\text { Deskriptif }\end{array}$ & Hasil \\
\hline \multirow[t]{12}{*}{1 Pretest } & \multirow[t]{6}{*}{ Kontrol } & $\mathrm{N}$ & 20 \\
\hline & & Skor Ideal & 45 \\
\hline & & Skor minimum & 1 \\
\hline & & Skor maximum & 9 \\
\hline & & Mean & 3,5 \\
\hline & & Std. Deviasi & 1,6 \\
\hline & \multirow{6}{*}{$\begin{array}{c}\text { Ekspe- } \\
\text { rimen }\end{array}$} & $\mathrm{N}$ & 20 \\
\hline & & Skor Ideal & 45 \\
\hline & & Skor minimum & 1 \\
\hline & & Skor maximum & 6 \\
\hline & & Mean & 3,4 \\
\hline & & Std. Deviasi & 1,6 \\
\hline \multirow[t]{12}{*}{2 Posttest } & \multirow[t]{6}{*}{ Kontrol } & $\mathrm{N}$ & 20 \\
\hline & & Skor Ideal & 45 \\
\hline & & Skor minimum & 4 \\
\hline & & Skor maximum & 21 \\
\hline & & Mean & 10,90 \\
\hline & & Std. Deviasi & 3,89 \\
\hline & \multirow{6}{*}{$\begin{array}{c}\text { Ekspe- } \\
\text { rimen }\end{array}$} & $\mathrm{N}$ & 20 \\
\hline & & Skor Ideal & 45 \\
\hline & & Skor minimum & 6 \\
\hline & & Skor maximum & 41 \\
\hline & & Mean & 18,6 \\
\hline & & Std. Deviasi & 11,16 \\
\hline
\end{tabular}

Dari Tabel 4, dapat dilihat bahwa secara umum rata-rata kemampuan penalaran matematis siswa berdasarkan pretes pada kedua kelas tersebut hampir setara hanya selisih 0,1. Sedangkan 
perolehan std. variansi juga sama yaitu 1.6 artinya penyebaran data pada kedua kelas tersebut sama. Sedangkan kemampuan penalaran matematis siswa berdasarkan postes terlihat berbeda. Secara umum dapat dilihat kemampuan penalaran matematis siswa pada kelas eksperimen lebih tinggi dari kelas kontrol.

Kemampuan penalaran matematis siswa di ukur berdasarkan 5 indikator yaitu (a). Kemampuan menyajikan

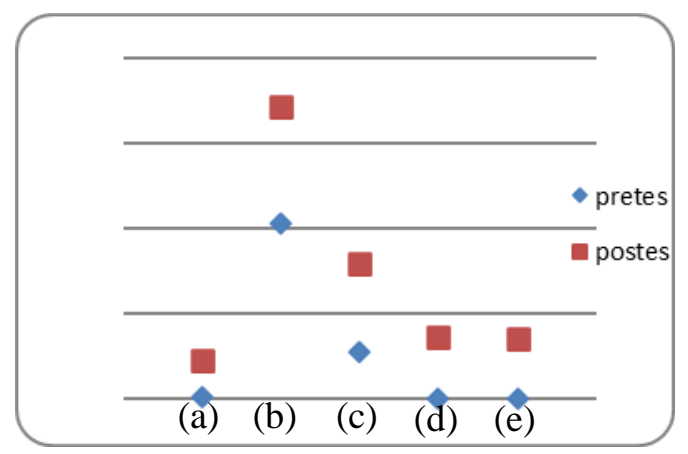

Kelas kontrol pernyataan matematika secara lisan, tertulis, gambar, dan diagram, (b) Kemampuan mengajukan dugaan, (c) Kemampuan melakukan manipulasi matematika, (d) Kemampuan menyusun bukti, memberikan alasan terhadap suatu solusi. (e) Kemampuan menarik kesimpulan dari pernyataan. Perolehan kemampuan penalaran matematis berdasarkan indikator tersebut dijabarkan pada Gambar 1.

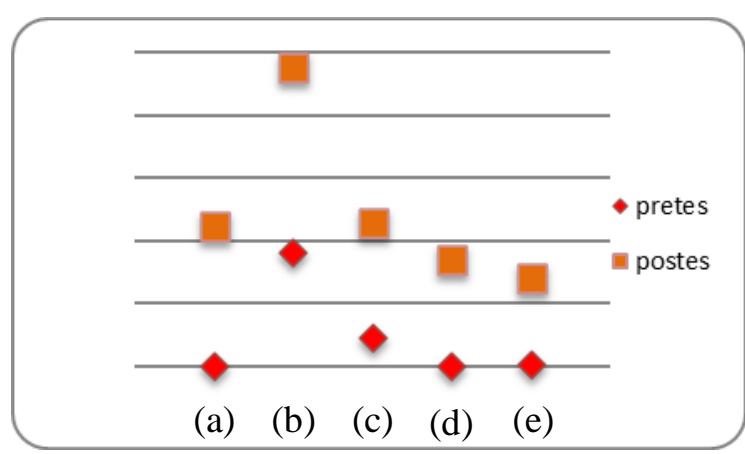

Kelas eksperimen

Gambar 1. Grafik kemampuan penalaran matematis siswa berdasarkan Berdasarkan indikator penalaran matematis

Berdasarkan Gambar 1, dapat dilihat bahwa ada peningkatan kemampuan penalaran matematis siswa disetiap indikator pada kelas eksperimen dan kontrol. Pada kelas eksperimen, indikator Kemampuan menyajikan pernyataan matematika secara lisan, tertulis, gambar, dan diagram meningkat sebanyak $22,30 \%$, Kemampuan mengajukan dugaan meningkat sebanyak 29,6\%, Kemampuan melakukan manipulasi matematika meningkat sebanyak $18,4 \%$, Kemampuan menyusun bukti, memberikan alasan terhadap suatu solusi meningkat sebanyak $13 \%$ dan Kemampuan menarik kesimpulan dari pernyataan meningkat sebanyak $13,7 \%$. Sedangkan pada kelas kontrol, indikator
Kemampuan menyajikan pernyataan matematika secara lisan, tertulis, gambar, dan diagram meningkat sebanyak 4,3\%, Kemampuan mengajukan dugaan meningkat sebanyak $13,7 \%$, Kemampuan melakukan manipulasi matematika meningkat sebanyak $10,4 \%$, Kemampuan menyusun bukti, memberikan alasan terhadap suatu solusi meningkat sebanyak $7,3 \%$ dan Kemampuan menarik kesimpulan dari pernyataan meningkat sebanyak $7 \%$.

Secara terperinci peningkatan kemampuan penalaran matematis siswa dapat dilihat dari perolehan nilai $\mathrm{N}$ Gain dari kelas eksperimen dan kelas kontrol pada Tabel 5. 
DOI: https://doi.org/10.24127/ajpm.v10i4.4211

Tabel 5. Statistika deskriptif nilai n-gain

\begin{tabular}{cccccc}
\hline Kelas & $\mathbf{N}$ & $\begin{array}{c}\text { Skor } \\
\text { terendah }\end{array}$ & $\begin{array}{c}\text { Skor } \\
\text { tertinggi }\end{array}$ & Rata-rata & Std.deviasi \\
\hline Eksperimen & 20 & 0,11 & 0,90 & 0,36 & 0,26 \\
Kontrol & 20 & 0.02 & 0,40 & 0,16 & 0,09 \\
\hline
\end{tabular}

Berdasarkan Tabel 5 dapat dilihat bahwa rata-rata nilai $\mathrm{N}$-Gain kelas eksperimen 0,36 dengan standar deviasi 0,26 . Sedangankan pada kelas kontrol rata-rata nilai $\mathrm{N}$-Gain 0,16 dengan Std.
Deviasi 0,09. Rincian presentase kemampuan penalaran matematis siswa berdasarkan kriteria N-Gain dapat dilihat pada Tabel 6 .

Tabel 6. Rincian persentase berdasarkan kriteria data n-gain

\begin{tabular}{ccccccc}
\hline \multirow{2}{*}{ Indeks Gain } & \multicolumn{3}{c}{ Kelas eksperimen } & \multicolumn{3}{c}{ Kelas kontrol } \\
\cline { 2 - 6 } & Jml & Interpretasi Persentase & Jml & Interpretasi Persentase \\
\hline $\mathrm{g} \geq 0,70$ & 4 & Tinggi & $20 \%$ & 0 & Tinggi & - \\
$0,3 \leq \mathrm{g}<0,70$ & 3 & Sedang & $15 \%$ & 19 & Sedang & $95 \%$ \\
$\mathrm{~g}<30$ & 13 & Rendah & $65 \%$ & 1 & Rendah & $5 \%$ \\
\hline
\end{tabular}

Pada Tabel 6, tampak bahwa peningkatan kemampuan penalaran matematis siswa pada kelas eksperimen pada kategori tinggi sebanyak $20 \%$ dan paling banyak berada pada kategori rendah yaitu $65 \%$. sedangkan pada kelas kontrol peningkatan kemampuan penalaran matematis siswa paling banyak pada kategori sedang yaitu 95\%.

Selanjutnya tahap analisis data dilanjutkan dengan pengujian hipotesis, namun terlebih dahulu dilakukan uji normalitas dan homogenitas sebagai syarat uji statistika parametrik.

\section{b. Uji Normalitas}

Tujuan melakukan uji normalitas yaitu untuk melihat apakah Sampel berasal dari sampel yang berdistribusi normal atau tidak. Hasil dari uji normal ini berguna untuk mengambil langkah pengujian hipotesis yang digunakan. Dalam hal ini statistika parametrik atau non parametrik yang digunakan. Adapun hasil uji normalitas dapat dilihat pada Tabel 7.

Tabel 7. Uji Normalitas data N-Gain

\begin{tabular}{llcccc}
\hline \multirow{2}{*}{ Kelas } & \multicolumn{2}{c}{ Kolmogorov-Smirnov ${ }^{\text {a }}$} & \multirow{2}{*}{ Keterangan } \\
\cline { 3 - 5 } & Statistic & df & Sig. & \\
\hline \multirow{2}{*}{ NGain_Score } & Eksperimen & .288 & 20 & .000 & Berdistribusi tidak normal \\
& Kontrol & .212 & 20 & .019 & Berdistribusi tidak normal \\
\hline
\end{tabular}

Pada Tabel 7, diperoleh nilai signifikansi pada kelas eksperimen 0,00 dan pada kelas kontrol 0,019. Nilai signifikansi kedua kelas tersebut lebih kecil dari 0,005. Hal ini menunjukkan bahwa data kedua kelas tersebut tidak berdistribusi normal, Sehingga pengujian hipotesis dilanjutkan dengan uji non parametrik yaitu menggunakan uji Mann Whitney. Hasil uji MannWhitney data N-Gain dapat dilihat pada Tabel 8. 
DOI: https://doi.org/10.24127/ajpm.v10i4.4211

Tabel 8. Uji Mann-Whitney data N-Gain

\begin{tabular}{lr}
\hline \multicolumn{2}{c}{ Test Statistics } \\
\hline & NGain_Score \\
Mann-Whitney U & 88.000 \\
Wilcoxon W & 298.000 \\
Z & -3.031 \\
Asymp. Sig. (2-tailed) & .002 \\
\hline
\end{tabular}

Berdasarkan hasil output Uji Mann Whitney Data N-Gain diperoleh $\mathrm{U}=88,000$ dan Nilai signifikansi 0,002 kurang dari 0,05 maka $H_{0}$ di tolak artinya Peningkatan kemampuan penalaran matematis siswa melalui media pembelajaran POLIBRA lebih baik dari pada melalui pembelajaran tanpa media POLIBRA pada materi program linear di kelas X SMKN 1 Langsa.

\section{c. Self Confidence}

Pada penelitian ini, angket selfconfident di sebarkan sebanyak dua kali pada masing-masing kelas eksperimen dan kelas kontrol. Sebaran angket selfconfidence Pertama disebarkan setelah siswa menyelesaikan pretes. Sebaran angket self-confidence yang kedua disebarkan setelah siswa menyelesaikan postes. Persentase hasil angket selfcofidence kelas eksperimen dapat dilihat pada Tabel 9.

Tabel 9. Rincian persentase dan kategori self-cofidence pada kelas eksperimen

\begin{tabular}{lccccc}
\hline & & Sebaran pertama & Sebaran kedua \\
\cline { 2 - 5 } Aspek Aspek Self Cofidence & $\begin{array}{c}\text { Persentase } \\
\text { skor yg } \\
\text { diperoleh }\end{array}$ & Kategori & $\begin{array}{c}\text { Persentase } \\
\text { skor yg } \\
\text { diperoleh }\end{array}$ & Kategori \\
\hline $\begin{array}{l}\text { Keyakinan terhadap } \\
\text { diri sendiri untuk } \\
\text { matematika }\end{array}$ & $\begin{array}{c}\text { kempuan } \\
\text { memami }\end{array}$ & $67,75 \%$ & Cukup & $80,25 \%$ & Baik \\
$\begin{array}{l}\text { Keyakinan } \\
\text { menyelesaikan diri masalah-masalah } \\
\text { matematik, dapat }\end{array}$ & $64,16 \%$ & Cukup & $70,41 \%$ & cukup \\
$\begin{array}{l}\text { Keyakinan diri untuk dapat terus } \\
\text { belajar matematika }\end{array}$ & $72,5 \%$ & Cukup & $79,58 \%$ & Baik \\
$\begin{array}{l}\text { Keyakinan diri dapat mengatasi } \\
\text { rintangan dalam menyelesaikan } \\
\text { masalah }\end{array}$ & $73,75 \%$ & Cukup & $79,37 \%$ & Baik \\
\hline
\end{tabular}

Tabel 10. Rincian persentase dan kategori self-cofidence pada kelas kontrol

\begin{tabular}{lcccc}
\hline & \multicolumn{2}{c}{ Sebaran pertama } & \multicolumn{2}{c}{ Sebaran Kedua } \\
\cline { 2 - 5 } Aspek-Aspek Self Cofidence & $\begin{array}{c}\text { Persentase } \\
\text { skor yg } \\
\text { diperoleh }\end{array}$ & Kategori & $\begin{array}{c}\text { Persentase } \\
\text { skor yg } \\
\text { diperoleh }\end{array}$ & Kategori \\
\hline $\begin{array}{l}\text { Keyakinan terhadap kemampuan } \\
\text { diri sendiri untuk memahami } \\
\text { matematika }\end{array}$ & $65,75 \%$ & Cukup & $76,75 \%$ & Baik \\
$\begin{array}{l}\text { Keyakinan diri dapat } \\
\text { menyelesaikan masalah-masalah } \\
\text { matematik, }\end{array}$ & $60,20 \%$ & Cukup & $67,91 \%$ & cukup \\
& & & & \\
\end{tabular}




\begin{tabular}{lcccc}
\hline & \multicolumn{2}{c}{ Sebaran pertama } & \multicolumn{2}{c}{ Sebaran Kedua } \\
\cline { 2 - 5 } Aspek-Aspek Self Cofidence & $\begin{array}{c}\text { Persentase } \\
\text { skor yg } \\
\text { diperoleh }\end{array}$ & Kategori & $\begin{array}{c}\text { Persentase } \\
\text { skor yg } \\
\text { diperoleh }\end{array}$ & Kategori \\
\hline $\begin{array}{l}\text { Keyakinan diri untuk dapat terus } \\
\text { belajar matematika }\end{array}$ & $71,66 \%$ & Cukup & $74,58 \%$ & cukup \\
$\begin{array}{l}\text { Keyakinan diri dapat mengatasi } \\
\text { rintangan dalam menyelesaikan } \\
\text { masalah }\end{array}$ & $71,56 \%$ & Cukup & $75 \%$ & cukup \\
\hline
\end{tabular}

Berdasarkan Tabel 9 dan 10, diperoleh informasi bahwa siswa pada kelas eksperimen dan kontrol sudah memiliki self-confidence pada kategori cukup. Setelah dilakukan pembelajaran dikedua kelas terlihat bahwa pada kelas eksperimen yang diajarkan dengan media polibra ada peningkatan selfconfidence pada aspek Keyakinan terhadap kemampuan diri sendiri untuk memahami matematika 80,25\% dengan kategori baik; aspek keyakinan diri untuk dapat terus belajar matematika $79,58 \%$ dengan kategori baik; dan aspek keyakinan diri dapat mengatasi rintangan dalam menyelesaikan masalah 79,37\% dengan kategori Baik. Sedangkan pada kelas kontrol peningkatan self-confidence terjadi pada aspek keyakinan terhadap kemampuan diri sendiri untuk memahami matematika $76,75 \%$ dengan kategori baik, aspek yg lainnya juga terlihat sedikit meningkat walaupun masih berada pada kategori cukup.

Berdasarkan hasil observasi siswa dan wawancara dengan guru, Siswa masih kesulitan dalam menggambarkan grafik dan menyelesaikan masalah yang berkaitan dengan suatu persamaan linier. Kurangnya pemanfaatan software dalam memecahkan masalah matematika sehingga siswa tidak tertarik atau sulit memahami materi persamaan linier.

Umumnya, guru masih menggunakan cara manual untuk menyelesaikan permasalahan matematika. Padahal pemamfaatan software dapat meningkatkan kualitas pembelajaran sehingga tidak menoton. Hal ini senada dengan (Rahmi \& Samsudi, 2020) media pembelajaran sangat penting terhadap kebutuhan belajar dan memudahkan kegiatan pembelajaran, sangat membantu keefektifan proses pembelajaran dan penyampaian pesan dan isi pelajaran.

Media PROLIBRA digunakan untuk membantu siswa memahami dan meningkatkan kemampuan penalaran pada konsep program linier. berdasarkan Hasil penelitian menunjukkan adanya peningkatan penalaran matematis dan selfconfidence, hal ini sejalan dengan penelitian Budiman (Budiman \& Rosmiati, 2020) yang menyatakan bahwa kemampuan penalaran matematis siswa yang mendapat pembelajaran dengan bantuan Geogebra lebih baik daripada kemampuan penalaran matematis siswa yang tidak mendapat bantuan Geogebra.

Selain itu, pemamfataan media POLIBRA juga membuat pembelajaran menjadi lebih menarik sehingga dapat meningkatkan Self confidence siswa. hal ini terlihat Pada saat proses pembelajaran berlangsung, siswa yang diajarkan dengan media POLIBRA terlihat lebih antusias dan sangat tertarik dalam mengikuti pembelajaran. Adanya peningkatan self-confidence pada siswa 
yang diajarkan dengan media POLIBRA. Hasil penelitian ini sejalan dengan penelitian Sholeha (Sholeha et al., 2019) yang menyatakan bahwa pemanfaatan TIK juga dapat meningkatkan kemampuan kepercayaan diri atau Self confidence siswa selama pembelajaran

Guru sangat berperan penting dalam peningkatan Self confidence siswa, guru dapat sangat mempengaruhi kepercayaan diri siswa; siswa tergantung pada bagaimana guru memperlakukan mereka. Mengingat pentingnya keterampilan ini, maka sekolah dan guru berkewajiban menumbuhkan dan mengembangkanya pada siswa, terutama Ketika siswa sedang menyelesaikan soal-soal yang memerlukan ketekunan dan berpikir keras.

\section{KESIMPULAN DAN SARAN}

Berdasarkan hasil analisa data, dapat disimpulkan bahwa peningkatan kemampuan penalaran matematis siswa melalui media pembelajaran POLIBRA lebih baik dari pada melalui pembelajaran tanpa media POLIBRA pada materi program linear di kelas $\mathrm{X}$ SMKN 1 Langsa. Disamping itu, terdapat peningkatan kepercayaan diri (Self-confidence) pada siswa kelas $\mathrm{X}$ SMKN 1 Langsa yang diajarkan dengan media POLIBRA, ada peningkatan pada aspek keyakinan terhadap kemampuan diri sendiri untuk memahami matematika $80,25 \%$ dengan kategori baik; aspek keyakinan diri untuk dapat terus belajar matematika 79,58\% dengan kategori baik; dan aspek keyakinan diri dapat mengatasi rintangan dalam menyelesaikan masalah 79,37\% dengan kategori Baik

Adapun saran untuk penelitian selanjutnya untuk mengembangkan bahan ajar berupa buku siswa berbasis PROLIBRA untuk meningkatkan kemampuan matematis siswa, afektif serta keterampilan siswa. Saran lain yaitu menyiapkan perangkat pembelajaran untuk proses pembelajaran jarak jauh.

\section{DAFTAR PUSTAKA}

Agustin, R. D. (2016). Kemampuan Penalaran Matematika Mahasiswa Melalui Pendekatan Problem Solving. PEDAGOGIA: Jurnal Pendidikan, 5(2), 179-188. https://doi.org/10.21070/pedagogi a.v5i2.249

Andayani, M., \& Amir, Z. (2019). Membangun Self-Confidence Siswa melalui Pembelajaran Matematika. Desimal: Jurnal Matematika, 2(2), 147-153. https://doi.org/10.24042/djm.v2i2. 4279

Arifendi, R. F., \& Setiawan, R. (2019). Upaya Peningkatan Penalaran Matematis Mahasiswa Universitas Tribhuana Tunggadewi Melalui Pendekatan Contextual And Learning (CTL). Journal PRISMATIKA, 1(2), 55-59. http://ejurnal.budiutomomalang.ac .id/index.php/prismatika/article/vi ew/435

Arikunto. (2010). Prosedur Penelitian: Suatu Pendekatan Praktek. Jakarta: Rineka Cipta.

Bernard, M. (2015). Meningkatkan Kemampuan Komunikasi Dan Penalaran Serta Disposisi Matematik Siswa SMK dengan Pendekatan Kontekstual Melalui Game Adobe Flash CS 4.0. Infinity Journal, 4(2), 197-222. https://doi.org/10.22460/infinity.v $4 \mathrm{i} 2.84$

Budiaji, W. (2013). Skala Pengukuran dan Jumlah Responden Skala 
DOI: https://doi.org/10.24127/ajpm.v10i4.4211

Likert (The Measurement Scale and The Number of Responses in Likert Scale). Jurnal Ilmu Pertanian Dan Perikanan Desember, 2(2), 127-133.

Budiman, H., \& Rosmiati, M. (2020). Penerapan Teori Belajar Van Hiele Berbantuan Geogebra untuk Meningkatkan Kemampuan Penalaran Matematis Siswa. Prisma, 9(1), 47-56. https://doi.org/10.35194/jp.v9i1.8 45

Fairman, K. A., Peckham, A. M., Rucker, M. L., Rucker, J. H., \& Sclar, D. A. (2018). Use of Power-Law Analysis to predict abuse or diversion of Prescribed Medications: Proof-of-Concept Mathematical Exploration. BMC Research Notes, 3(5), 1-8. https://doi.org/https://doi.org/10.1 186/s13104-018-3632-y

Fairus. (2015). Pengembangan Perangkat Pembelajaran Berbasis Model Discovery Learning Berbantuan Autograph Untuk Meningkatkan Kemampuan Penalaran Matematis Dan Keterampilan Sosial Siswa SMK. Prosiding Seminar Nasional Pendidikan Matematikaa Ke-3.

Fairus, \& Sari, R. P. (2020). Pengembangan Media Grapertalibra dengan Pendekatan Discovery Learning Untuk Meningkatkan Pemahaman Konsep dan Keterampilan Sosial Media. Journal of Authentic Research on Mathematics, 2(2), 201-213.

http://jurnal.unsil.ac.id/index.php/ jarme/article/view/1730

Larson, L. C., \& Miller, T. N. (2011). 21st Century Skills: Prepare
Students for the Future. Kappa Delta Pi Record, 47(3), 121-123. https://doi.org/10.1080/00228958. 2011.10516575

Minarni, A., Napitipulu, E. E., \& Lubis, S. D. (2020). Kemampuan Berfikir Matematis dan Aspek Afektif Siswa. Medan: Harapan Cerdas.

Pratiwi, D. D. (2016). Pembelajaran Learning Cycle 5E berbantuan Geogebra terhadap Kemampuan Pemahaman Konsep Matematis. Al-Jabar: Jurnal Pendidikan Matematika, 7(2), 191-202. https://doi.org/10.24042/ajpm.v7i 2.34

Rahmi, M. N., \& Samsudi, M. A. (2020). Pemanfaatan Media Pembelajaran Berbasis Teknologi sesuai Dengan Karakteristik Gaya Belajar. EDUMASPUL: Jurnal Pendidikan, 4(2), 355-363. https://ummaspul.ejournal.id/maspuljr/article/view/4 39

Sajidan, Baedhowi, Triyanto, Salman A.T, M. M. (2018). Peningkatan Proses Pembelajaran Dan Penilaian Pembelajaran Abad 21 Dalam Meningkatkan Kualitas Pembelajaran SMK. In Kemendikbud. Kemendikbud.

Sholeha, L. A., Novianti, D., \& Chotimah, S. (2019). Pengaruh Media ICT Berbasis for VBA Excel Terhadap Self Confidence Matematis Siswa SD Pada Materi Bangun Ruang. Journal On Education, 02(01), 104-109.

Sugiyono, P. D. (2016). metode penelitian kuantitatif, kualitatif,dan $R \& D . \quad$ Bandung: CV. Alvabeta.

Sunaryo, A. (2019). Penggunaan Media 
DOI: https://doi.org/10.24127/ajpm.v10i4.4211

Pembelajaran GeoGebra terhadap Hasil Belajar Siswa tentang Materi Program Linier Kelas X. Journal on Education, 02(01), 96-103.

http://jonedu.org/index.php/joe/art icle/view/270

Zulkarnaen, R. (2016). Penerapan Pendekatan Realistik Berbantuan ICT Terhadap Kemampuan Penalaran Matematis Siswa Kelas Vii. JUrnal Euclid, 3(2), 578587.

https://doi.org/10.33603/e.v3i2.33

4 